\title{
Impact of Acetyl Acetone on Zinc Uptake and Oxidative Stress in Cucumber (Cucumis sativus)
}

\author{
Usman Bashir Mahmud ${ }^{1}$, Ishaq Yahaya Lawan ${ }^{2}$ and M. S. Dagari ${ }^{2}$ \\ ${ }^{1}$ Department of Chemistry, Nigerian Army University, Biu, Nigeria \\ ${ }^{2}$ Department of Chemistry, Kano University of Science and Technology, Wudil, Nigeria
}

\section{Abstract}

The purpose of this research is to determine the impacts of acetyl acetone on zinc uptake and oxidative stress in cucumber (Cucumis sativus) seedlings grown in hydroponic solutions. Thirty seedlings of cucumber were collected from Kura local government area Kano, Kano state. Concentrations of $\mathrm{Zn}^{2+}$ in the hydroponics were varied from 0.000 to $0.025 \mathrm{~mol} \mathrm{dm}^{-3}$ and of acetyl acetone were also varied from 0.000 to $0.025 \mathrm{~mol} \mathrm{dm}^{-3}$. The seedlings were replanted and kept at Department of Agriculture Kano University of Science and Technology, Wudil garden. The weight of plants increased significantly ( $\mathrm{p}<0.05)$ with concentration of $\mathrm{Zn}^{2+}$ in the absence of acetyl acetone and highly insignificantly $(p>0.05)$ with concentration of acetyl acetone in the absence of $\mathrm{Zn}^{2+}$. In the presence of acetyl acetone and $\mathrm{Zn}^{2+}$ plant weight decreased highly insignificant $(\mathrm{p}>0.05)$. Leaf fall was observed from plants in all hydroponic, the number of falling leaves was insignificant $(\mathrm{p}>0.05)$ with concentration of $\mathrm{Zn}^{2+}$ but it is insignificant ( $p>0.05$ ) with concentration of acetyl acetone and highly insignificant in the presence of acetyl acetone and $\mathrm{Zn}^{2+}(\mathrm{p}>0.05)$. The volume of the solution decreased highly significant $(\mathrm{p}<0.05)$ with concentration of $\mathrm{Zn}^{2+}$ and significant with concentration of acetyl acetone $(p<0.05)$ the volume also increased insignificantly in the presence of acetyl acetone and $\mathrm{Zn}^{2+}(\mathrm{p}>0.05)$. The $\mathrm{pH}$ values of treated hydroponics before replanting and after harvest

Received: October 30, 2019; Accepted: December 26, 2019

Keywords and phrases: hydroponic, Cucumis sativus, seedling, oxidative stress, carotenoid, proline, chlorophyll..

Copyright () 2020 Usman Bashir Mahmud et al. This is an open access article distributed under the Creative Commons Attribution License, which permits unrestricted use, distribution, and reproduction in any medium, provided the original work is properly cited. 
were insignificant with increased in the concentration of $\mathrm{Zn}^{2+}(\mathrm{p}>0.05)$. Both shoot and root zinc accumulated were insignificant at lower concentration of $\mathrm{Zn}^{2+}(\mathrm{p}>0.05)$ and significant at higher concentration of $\mathrm{Zn}^{2+}(\mathrm{p}<0.05)$. The zinc translocation factor decreased highly insignificantly $(\mathrm{p}>0.05)$ at lower concentration of $\mathrm{Zn}^{2+}$ and significant at higher concentration of $\mathrm{Zn}^{2+}(\mathrm{p}>0.05)$ in treated plants compared to control. The chlorophyll, carotenoid and proline content varied in the presence and absence of acetyl acetone and or combination of the two, with $(\mathrm{p}<0.05)$ or $(\mathrm{p}>0.05)$.

\section{Introduction}

Zinc is an essential mineral that is naturally present in some food, added to other and available as a dietary supplement. Zinc is also found in many cold lozenges and some over the counter drugs sold as cold remedies.

Zinc is involved in numerous aspects of cellular metabolism. It is required for the catalytic activity of approximately 100 enzymes (Sandstead [36]) and it plays a role in immune function (Solomons [38]), protein synthesis (Prasad [32]), wound healing (Heyneman [16]), DNA synthesis (IMFNB [18]) and cell division (Prasad et al. [31]). Zinc also supports normal growth and development during pregnancy, childhood, and adolescence (Simmer and Thompson [37]) and is required for proper sense of taste and smell (Prasad et al. [31]). A daily intake of zinc is required to maintain a steady state because the body has no specialized zinc storage system (Rink [35]).

Zinc is present in several products, include some labeled as homeopathic medications, sold over the counter for the treatment and prevention of cold. Numerous case reports to anosmia (loss of the sense of smell), in some cases long lasting or permanent, have been associated with the use of zinc containing nasal gels or sprays (Jafek et al. [19]). In June 2009 the FDA warned consumers to stop using three zinc containing intranasal products because they might cause anosmia (US Food and Drugs Administration). The manufacture recalled these products from the market place. Currently, these safety concerns have not been found to be associated with cold lozenges containing zinc.

Zinc is also present in some denture adhesive creams at levels ranging from 17-34 $\mathrm{mg} / \mathrm{g}$ (Nations et al. [27]). While use of these products as directed (0.5-1.5 g/day) in not of concern, chronic, excessive use can lead to zinc toxicity, resulting in copper deficiency and neurologic disease. Such toxicity has been reported in individuals who 
used 2 or more standard $2.4 \mathrm{oz}$ tubes of denture cream per week (Nations et al. [27]), many denture creams have now been reformulated to eliminate zinc.

Zinc deficiency is characterized by growth retardation, loss of appetite and impaired immune function in more severe cases zinc deficiency causes hair loss, diarrhea, delayed sexual maturation, impotence, hypogonadism in males and eye and skin lesions (Prasad [30]). Zinc nutritional status is difficult to measure adequately using laboratory tests (Hunt [17]) due to its distribution throughout the body as a component of various proteins and nucleic acid (Hambidge and Krebs [12]). Plasma or serum zinc levels are the most commonly used indices for evaluating zinc deficiency but these levels do not necessarily reflect cellular zinc status due to tight homeostatic control mechanism (Maret and Sandstead [25]). Clinical effect of zinc deficiency can by present in the absence of abnormal laboratory indices (Maret and Sandstead [25]). Clinicians consider risk factors (such as inadequate caloric intake, alcoholism, and digestive disease) and symptoms of zinc deficiency (such as impaired growth in infacts and children). When determining the need for zinc supplementation (IMFNB [18]).

\section{Cucumber (Cucumis sativas)}

Cucumber (Cucumis sativas) is a widely cultivated plant in the gourd family, cucurbitacea. It is a creeping vine that bears cylindrical fruits that are used as culinary vegetables. There are three main varieties of cucumber there are: slicing, pickling and burpless. Within these varieties, several different cultivars have emerged. The cucumber is many different varieties are traded in the global market.

\section{Morphology of Cucumber (Cucumis sativas)}

The cucumber is a creeping vine that roots in the ground and grows up trellises or other supporting frames, wrapping around supports with thin, spiraling tendrils. The plants have large leaves that form a canopy over the fruit. The fruits of the cucumber is roughly cylindrical, elongated with tapered end, and may be as large as 60 centimeters (24 in) long and 10 centimeters (3.9 in) in diameter. Having an enclosed seed and developing from a flower, botanically speaking, cucumbers are classified as pepoes, a type of botanical berry much like tomatoes and squash they are often also perceived, prepared and eaten as vegetable cucumbers are usually more than $90 \%$ water.

\section{Flowering and Pollination}

A few cultivars of cucumber are parthenocarpic, the blossoms creating seedless fruit 
without pollination for these cultivars degrades the quantity. In the united state, these are usually grown in greenhouses where bees are excluded. In Europe, they are grown outdoors in some region, and bees are excluded from these areas.

Most cucumbers cultivars, however, are seeded and require pollination. Thousands of hives of honey bees are annually carried to cucumber field just before bloom for this purpose. Cucumbers may also be pollinated by bumblebees and several other bee species. Most cucumbers that require pollination are self-incompatible, so pollen from different plants is required to form seeds and fruit (Nonnecke [28]). Some selfcompatible cultivars exist that are related to the lemon cultivars (Nonnecke [28]). Symptoms of inadequate pollination include fruit abortion and misshapen fruit. Partially pollinated flowers may develops fruit that are green and develop normally near the stem end, but are pale yellow and withered at the blossom end.

Traditional cultivars produce male blossoms fruit, then female, in about equivalent numbers. Never gynoecious hybrid cultivars produce almost all female blossoms. They may have a pollenizer cultivars interplanted, and the number of beehives per unit area is increased, but temperature changes induce male flowers even on these plants, which may be sufficient for pollination to occur (Nonnecke [28]).

\section{Hydroponics}

Hydroponics is a set of hydroculture and is a method of growing of plants using mineral nutrient solutions, in water, without soil. Terrestrial plants may be grown with their roots in the mineral nutrient solution only, or in an inert medium, such as perlite or gravel. Hydroponics offers opportunities to provide optimal conditions for plant growth and therefore, higher yields can be obtained using it compared to open field production. It offers a means of control over soil-borne diseases and pests, which is especially desirable in the tropics where the life cycles of these organisms continue uninterrupted and so do the threat of infestation. Under hydroponics, some plants can be grown closer together than in the field because roots are directly fed; and multiple cropping can be practiced (Jensen [20]).

\section{Materials and Methods}

\section{Sample Collection}

Thirty seedlings of cucumber where collected in Kura local government area, Kano state. On 16/11/2015 By 1:05pm. 


\section{Identification}

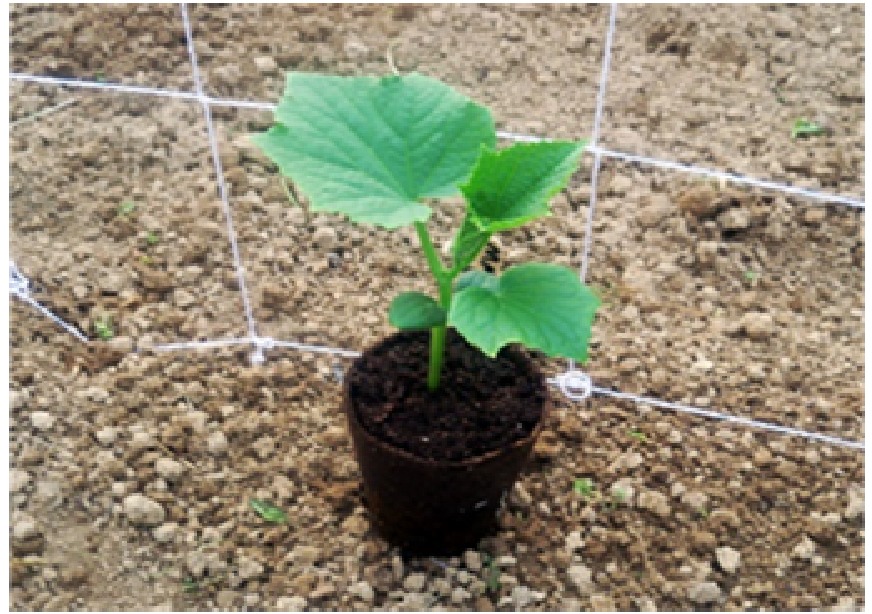

Seedlings were identified by Baha'uddeen Said Adam of the Department of Plant Science, Bayero University, Kano.

\section{Treatment}

The cucumber seedlings were washed thoroughly with tap water and then rinsed with deionized water.

\section{Reagents}

Boric acid $\left(\mathrm{H}_{3} \mathrm{BO}_{3}\right)$, Disodium dihydrogen pyrophosphate $\left(\mathrm{Na}_{2} \mathrm{H}_{2} \mathrm{P}_{2} \mathrm{O}_{7}\right)$, Hydrated calcium nitrate $\left(\mathrm{Ca}\left(\mathrm{NO}_{3}\right)_{2} \cdot 4 \mathrm{H}_{2} \mathrm{O}\right)$, Hydrated iron (III) chloride $\left(\mathrm{FeCl}_{3} \cdot 6 \mathrm{H}_{2} \mathrm{O}\right)$, Hydrated manganese sulphate $\left(\mathrm{MnSO}_{4} \cdot \mathrm{H}_{2} \mathrm{O}\right)$, Magnesium sulphate monohydrate $\left(\mathrm{MgSO}_{4} \cdot \mathrm{H}_{2} \mathrm{O}\right)$, Nitric acid $\left(\mathrm{HNO}_{3}\right)$, Potassium iodide $(\mathrm{KI})$, Potassium nitrate $\left(\mathrm{KNO}_{3}\right)$, Zinc nitrate $\mathrm{Zn}\left(\mathrm{NO}_{3}\right)$, Acetyl acetone.

\section{Preparation of Hydroponic Mixtures Control}

The control contained $2.56 \times 10^{-6} \mathrm{~mol} \mathrm{dm}^{-3} \mathrm{KNO}_{3}, 5.0 \times 10^{-4} \mathrm{~mol} \mathrm{dm}{ }^{-3} \mathrm{MgSO}_{4} \cdot \mathrm{H}_{2} \mathrm{O}$, $1.03 \times 10^{-3} \mathrm{~mol} \mathrm{dm}^{-3} \mathrm{FeCl}_{3} .6 \mathrm{H}_{2} \mathrm{O}, 2.50 \times 10^{-6} \mathrm{~mol} \mathrm{dm}^{-3} \mathrm{KI}, 2.31 \times 10^{-3} \mathrm{~mol} \mathrm{dm}^{-3}$ $\mathrm{MnSO}_{4} \cdot \mathrm{H}_{2} \mathrm{O}, 2.27 \times 10^{-3} \mathrm{~mol} \mathrm{dm}^{-3} \mathrm{H}_{3} \mathrm{BO}_{3}, 3.57 \times 10^{-4} \mathrm{~mol} \mathrm{dm}{ }^{-3} \mathrm{Ca}\left(\mathrm{NO}_{3}\right)_{2} \cdot 4 \mathrm{H}_{2} \mathrm{O}$, $5.0 \times 10^{-4} \mathrm{~mol} \mathrm{dm}^{-3} \mathrm{Na}_{2} \mathrm{H}_{2} \mathrm{P}_{2} \mathrm{O}_{7} 0.10 \mathrm{~mol} \mathrm{dm}^{-3} \mathrm{HNO}_{3} .500 \mathrm{~cm}^{3}$ of the control was prepared by pipetting $1.28 \mathrm{~cm}^{3}$ of $0.10 \mathrm{~mol} \mathrm{dm}^{-3} \mathrm{KNO}_{3}, 5.15 \mathrm{~cm}^{3}$ of $0.10 \mathrm{~mol} \mathrm{dm}^{-3}$ 
$\mathrm{FeCl}_{3} \cdot 6 \mathrm{H}_{2} \mathrm{O}, 11.35 \mathrm{~cm}^{3}$ of $0.10 \mathrm{~mol} \mathrm{dm}^{-3} \mathrm{H}_{3} \mathrm{BO}_{3}, 5.00 \mathrm{~cm}^{3}$ of $0.05 \mathrm{~mol} \mathrm{dm}^{-3}$ $\mathrm{MgSO}_{4} \cdot \mathrm{H}_{2} \mathrm{O}, 3.57 \mathrm{~cm}^{3}$ of $0.05 \mathrm{~mol} \mathrm{dm}{ }^{-3} \mathrm{Ca}\left(\mathrm{NO}_{3}\right)_{2} \cdot 4 \mathrm{H}_{2} \mathrm{O}, 5.00 \mathrm{~cm}^{3}$ of $0.05 \mathrm{~mol} \mathrm{dm}^{-3}$ $\mathrm{Na}_{2} \mathrm{H}_{2} \mathrm{P}_{2} \mathrm{O}_{7}, 0.17 \mathrm{~cm}^{3}$ of $0.0075 \mathrm{~mol} \mathrm{dm}^{-3} \mathrm{KI}, 23.10 \mathrm{~cm}^{3}$ of $0.05 \mathrm{~mol} \mathrm{dm}^{-3}$ $\mathrm{MnSO}_{4} \cdot \mathrm{H}_{2} \mathrm{O}$, and $5.00 \mathrm{~cm}^{3}$ of $0.10 \mathrm{~mol} \mathrm{dm}^{-3} \mathrm{HNO}_{3}$ into a $500 \mathrm{~cm}^{3}$ volumetric flask. The volume was made to mark with deionized water.

\section{Hydroponics Containing $0.0025 \mathrm{~mol} \mathrm{dm}^{-3}$ and $0.025 \mathrm{~mol} \mathrm{dm}^{-3} \mathrm{Zn}\left(\mathrm{NO}_{3}\right)_{2}$}

$500 \mathrm{~cm}^{3}$ of a hydroponic containing $0.0025 \mathrm{~mol} \mathrm{dm}^{-3} \mathrm{Zn}\left(\mathrm{NO}_{3}\right)_{2}$ was prepared by pipetting $5 \mathrm{~cm}^{3}$ of $0.25 \mathrm{~mol} \mathrm{dm}{ }^{-3} \mathrm{Zn}\left(\mathrm{NO}_{3}\right)_{2}$ into a $500 \mathrm{~cm}^{3}$ volumetric flask. The volume was made to mark with deionized water after adding the other components as in the control. Similarly, hydroponics containing $0.025 \mathrm{~mol} \mathrm{dm}^{-3}$ zinc nitrate was prepared by pipetting $50 \mathrm{~cm}^{3}$ of $0.25 \mathrm{~mol} \mathrm{dm}{ }^{-3} \mathrm{Zn}\left(\mathrm{NO}_{3}\right)_{2}$ into a $500 \mathrm{~cm}^{3}$ volumetric flask. The volume was made to mark with deionized water after adding the other components.

Hydroponics Containing $0.0025 \mathrm{~mol} \mathrm{dm}^{-3} \mathrm{Zn}\left(\mathrm{NO}_{3}\right)_{2}$ and $0.005 \mathrm{~mol} \mathrm{dm}^{-3}$ Acetyl Acetone

$500 \mathrm{~cm}^{3}$ of a hydroponic containing $0.0025 \mathrm{~mol} \mathrm{dm}^{-3} \mathrm{Zn}\left(\mathrm{NO}_{3}\right)_{2}$ and $0.005 \mathrm{~mol} \mathrm{dm}$ acetyl acetone was prepared by pipetting $5 \mathrm{~cm}^{3}$ of $0.25 \mathrm{~mol} \mathrm{dm}{ }^{-3} \mathrm{Zn}\left(\mathrm{NO}_{3}\right)_{2}$ and $10 \mathrm{~cm}^{3}$ of $0.25 \mathrm{~mol} \mathrm{dm}^{-3}$ acetyl acetone into a $500 \mathrm{~cm}^{3}$ volumetric flask. The volume was made to mark with deionized water after adding the other components. Other hydroponics mixtures containing different concentrations of $\mathrm{Zn}\left(\mathrm{NO}_{3}\right)_{2}$ and acetyl acetone were prepared by adding appropriate volumes of reagent and diluting to $500 \mathrm{~cm}^{3}$ with deionised water.

\section{$1000 \mathrm{mg} / \mathrm{dm}^{3} \mathrm{Zn}^{2+}$ Solution}

$2.8970 \mathrm{~g}$ of $\mathrm{Zn}\left(\mathrm{NO}_{3}\right)_{2}$ was dissolved in a $400 \mathrm{~cm}^{3}$ beaker containing $100 \mathrm{~cm}^{-3}$ deionised water and $10 \mathrm{~cm}^{3}$ of $10 \%$ nitric acid. The solution was transferred into a 1000 $\mathrm{cm}^{3}$ volumetric flask and made to mark with deionized water.

\section{$100 \mathrm{mg} / \mathrm{dm}^{3} \mathrm{Zn}^{2+}$ Solution}

$10 \mathrm{~cm}^{3}$ of $1000 \mathrm{mg} / \mathrm{dm}^{3} \mathrm{Zn}^{2+}$ solution was pipetted into a $100 \mathrm{~cm}^{3}$ volumetric flask, diluted and made to mark with deionised water. 


\section{Replanting of Cucumber Seedlings}

Pre-treated cucumber seedlings were separately replanted in $500 \mathrm{~cm}^{3}$ of hydroponics containing $0.0000,0.0025,0.025 \mathrm{~mol} \mathrm{dm}^{-3} \mathrm{Zn}\left(\mathrm{NO}_{3}\right)_{2}$ with $0.000,0.005,0.250 \mathrm{~mol} \mathrm{dm}^{-3}$ acetyl acetone respectively in clean $750 \mathrm{~cm}^{3}$ table water plastic bottles on the 5 th August, 2015 around 10:00am. Each treatment was replicated three times. The replanted seedlings were kept in the garden of fishery and wildery department of agriculture in Kano University of Science and Technology Kano.

\section{Harvesting of Seedlings}

All the seedlings were harvested at the same time i.e. on 19/11/2015 at 12:47pm. The harvested seedlings were washed with $1 \%$ nitric acid and rinsed thoroughly with deionized water and dried.

\section{Atomic Absorption Spectrometric Analysis}

Two grams of each vegetables will was weighed in different crucibles. One milliliter of concentrated nitric acid was added and then pre-ashed by placing the crucibles on a heater until the contents turned black. The pre-ashed samples were then transferred into a muffle furnace with a temperature of $480^{\circ} \mathrm{C}$ for 3 hours, after which they cooled to room temperature. The cooled samples were dissolved using $5 \mathrm{ml}$ of $30 \% \mathrm{HCl}$ and then filtered using whatman filter papers. The filtrates were individually poured in to $50 \mathrm{ml}$ standard flask and made up to the mark with deionized water. These were then transferred into prewashed sample bottles for analysis of the zinc metal using GBC atomic absorption spectrophotometer.

\section{Chlorophyll and Carotenoid Analysis}

Chlorophyll estimation of leaves of treated and control plants were done according to the method of Arnon (1949). Two hundred milligram (0.2g) of fresh leaf tissues of each sample were homogenized using chilled acetone in a test tubes. The homogenate was centrifuge for 10 minutes and the supernatant was collected. The residue was again extracted with $80 \%$ acetone and centrifuged. The supernatant was pooled together and the extraction process was repeated until the residue become colourless. The volume of the combined supernatant was noted. The absorbance of the solution was measured against the solvent (80\% acetone) at $645 \mathrm{~nm}, 663 \mathrm{~nm}$ and $470 \mathrm{~nm}$ for chlorophyll A, chlorophyll B and carotenoid respectively. 


\section{Proline Analysis}

The plant material was homogenized in $3 \%$ aqueous sulfosalicylic acid $(0.01 \mathrm{~g} / 0.5$ $\mathrm{ml}$ ) and the residue is removed by centrifugation at 3000r for 10 minutes. $1 \mathrm{ml}$ of homogenized tissue reacts with $1 \mathrm{ml}$ acid-ninhydrin and $1 \mathrm{ml}$ glacial acetic acid in a test tube and heated for 1 hour at $100^{\circ} \mathrm{C}$ and the reaction is terminated in an ice bath.

The reaction mixture was extracted with $2 \mathrm{ml}$ toluene, mixed vigorously and left at room temperature for 30 minutes until separation of two phases.

The chromophore-containing toluene ( $1 \mathrm{ml}$, upper phase) is warmed to room temperature and it is optical activity is measured at $520 \mathrm{~nm}$ using toluene as a blank.

The proline concentration is determined from a standard curve using D-proline.

\section{Data Analysis}

The data were analyzed through one-way analysis of variance (ANOVA) to determine the effect of treatments, and least significant difference (LSD) tests were performed to determine the statistical significance of the differences between means of treatments.

\section{Results and Discussion}

\section{Monitoring the Growth of Replanted Seedlings}

Table 3.1A. Changes in physiological parameters observed during the growth of seedlings.

\begin{tabular}{|c|c|c|c|}
\hline $\mathbf{Z n}$ & $\mathbf{A A}$ & $\boldsymbol{\Delta W P}$ & $\boldsymbol{\Delta V}$ \\
\hline 0.0000 & 0.0000 & $-21.600 \pm 2.343$ & $-106.667 \pm 15.275$ \\
\hline 0.0025 & 0.0000 & $-19.000 \pm 3.251$ & $-96.667 \pm 25.166$ \\
\hline 0.0250 & 0.0000 & $-11.933 \pm 2.875$ & $-76.667 \pm 5.774$ \\
\hline 0.0000 & 0.0050 & $-29.500 \pm 9.528$ & $-76.667 \pm 15.275$ \\
\hline 0.0000 & 0.0250 & $-17.500 \pm 2.088$ & $-93.333 \pm 5.774$ \\
\hline 0.0025 & 0.0050 & $-14.633 \pm 3.037$ & $-88.333 \pm 12.583$ \\
\hline 0.0025 & 0.0250 & $-16.367 \pm 2.984$ & $-88.667 \pm 5.774$ \\
\hline
\end{tabular}


Impact of Acetyl Acetone on Zinc Uptake and Oxidative Stress in Cucumber ...

\begin{tabular}{|l|l|l|l|}
\hline 0.0250 & 0.0050 & $-10.733 \pm 3.089$ & $-73.333 \pm 15.275$ \\
\hline 0.0250 & 0.0250 & $-7.600 \pm 2.883$ & $-71.666 \pm 7.638$ \\
\hline
\end{tabular}

Abbreviations: $\mathrm{AA}=$ acetyl acetone, $\Delta \mathrm{WP}=$ change in plant weight, $\Delta \mathrm{V}=$ change in volume of solution.

Table 3.1B. ANOVA output for changes in physiological parameters.

\begin{tabular}{|c|c|c|c|c|c|c|}
\hline Parameter & Source & DF & SS & MS & $\mathbf{F}$ & P-value \\
\hline \multirow[t]{3}{*}{$\Delta \mathrm{WP}$} & $\begin{array}{c}\Delta \mathrm{Zn}^{2+} \\
+ \\
0.000 \mathrm{AA}\end{array}$ & 1 & 239.6433 & 239.6433 & 0.048349 & 0.048349 \\
\hline & $\begin{array}{c}\Delta \mathrm{AA} \\
+ \\
0.000 \mathrm{Zn}^{2+}\end{array}$ & 1 & 552.9552 & 552.9552 & 15.35982 & 0.059366 \\
\hline & $\begin{array}{c}\Delta \mathrm{Zn}^{2+} \\
+ \\
\Delta \mathrm{AA}\end{array}$ & 2 & 406.5757 & 203.2879 & 39.32648 & $3.56 \mathrm{E}-05$ \\
\hline \multirow[t]{3}{*}{ NFL } & $\begin{array}{c}\Delta \mathrm{Zn}^{2+} \\
+ \\
0.000 \mathrm{AA}\end{array}$ & 1 & 0.000189 & 0.000189 & 1.493827 & 0.346118 \\
\hline & $\begin{array}{c}\Delta \mathrm{AA} \\
+ \\
0.000 \mathrm{Zn}^{2+}\end{array}$ & 1 & 0.000225 & 0.000225 & 2.25 & 0.272393 \\
\hline & $\begin{array}{c}\Delta \mathrm{Zn}^{2+} \\
+ \\
\Delta \mathrm{AA} \\
\end{array}$ & 2 & 0.000554 & 0.000277 & 2.751724 & 0.116807 \\
\hline \multirow[t]{3}{*}{$\Delta \mathrm{V}$} & $\begin{array}{c}\Delta \mathrm{Zn}^{2+} \\
+ \\
0.000 \mathrm{AA}\end{array}$ & 1 & 7513.495 & 7513.495 & 75.13485 & 0.013049 \\
\hline & $\begin{array}{c}\Delta \mathrm{AA} \\
+ \\
0.000 \mathrm{Zn}^{2+}\end{array}$ & 1 & 9027.85 & 9027.85 & 3249.909 & 0.000308 \\
\hline & $\begin{array}{c}\Delta \mathrm{Zn}^{2+} \\
+ \\
\Delta \mathrm{AA}\end{array}$ & 2 & 17072.8 & 8536.4 & 337.2906 & $3.45 \mathrm{E}-09$ \\
\hline
\end{tabular}

Abbreviations: $\mathrm{AA}=$ acetyl acetone, $\Delta \mathrm{WP}=$ change in plant weight, $\mathrm{NFL}=$ number of falling leaves, $\Delta \mathrm{V}=$ change in volume.

Table 3.1B shows the changes in plant weight, number of fallen leaves and volume of hydroponic solutions. 
They were evaluated using the relations;

- $\quad \Delta \mathrm{WP}(\mathrm{g})=($ Weight of plant after harvest $)-$ (Weight of plant before replanting $)$.

- $\quad \mathrm{NFL}=$ Total number of fallen leaves.

- $\Delta \mathrm{V}=$ (volume of solution after harvest $)-($ volume of solution before replanting).

\section{Change in Plant Weight $(\Delta W P)$}

The change in plant weight for all treatments including the control was determined by taking the difference between the weight of plant before replanting and the weight of plant after harvest. The change in plant weight $(\Delta \mathrm{WP})$ for the control was $-21.600 \pm 2.343 \mathrm{~g}$. Values of $\Delta \mathrm{WP}$ for 0.0025 and $0.025 \mathrm{~mol} \mathrm{dm}^{-3} \mathrm{Zn}^{2+}$ were $-19.000 \pm 3.251 \mathrm{~g}$ and $-11.933 \pm 2.875 \mathrm{~g}$ respectively. The correlation of $\mathrm{Zn}^{2+}$ with $\Delta \mathrm{WP}$ was significant $(\mathrm{p}>0.05)$. For a given concentration of $\mathrm{Zn}^{2+}$ at different concentrations of acetyl acetone, the change in plant weight was also determined, For $0.0025 \mathrm{~mol} \mathrm{dm}^{-3}$, the values of $\Delta \mathrm{WP}$ were $-29.500 \pm 9.528,-17.500 \pm 2.088$ and $-14.633 \pm 3.037 \mathrm{~g}$, for 0.000 , 0.005 and $0.025 \mathrm{~mol} \mathrm{dm}^{-3}$ acetyl acetone respectively. The corresponding values of $\Delta \mathrm{WP}$ for $0.025 \mathrm{~mol} \mathrm{dm}^{-3}$ were $-16.367 \pm 2.984,-10.733 \pm 3.089$ and $-7.600 \pm 2.883$ for $0.000,0.005$ and $0.025 \mathrm{~mol} \mathrm{dm}^{-3}$ acetyl acetone respectively. However, the correlation of acetyl acetone with $\triangle \mathrm{WP}$ was insignificant $(\mathrm{p}>0.05)$.

\section{Number of Fallen Leaves (NFL)}

The fallen of leaves was observed during growth of the Cucumbar (Cucumis sativus) seedlings in both control and other hydroponic treatments. The addition of $\mathrm{Zn}^{2+}$ in the absence of acetyl acetone shows an insignificant fallen of leaves ( $p>0.05)$, while the addition acetyl acetone could not cause insignificant fallen of leaves ( $p>0.05)$. However, the changes due to addition of $\mathrm{Zn}^{2+}$ with acetyl acetone were insignificant $(\mathrm{p}>0.05)$.

\section{Change in Volume of Solutions $(\Delta \mathrm{V})$}

Volume of hydroponic solution was taken before replanting and after harvesting of replanted Cucumber (Cucumis sativus) seedlings for both the control and other hydroponic treatments. The presence of $\mathrm{Zn}^{2+}$ and absence of acetyl acetone showed a significant decrease in volume $(\mathrm{p}<0.05)$. Only In the presence of acetyl acetone, the volume decreased significantly $(\mathrm{p}<0.05)$. However, the addition of $\mathrm{Zn}^{2+}$ with acetyl acetone gives insignificant change in volume $(\mathrm{p}>0.05)$. 


\section{Changes in Chlorophyll}
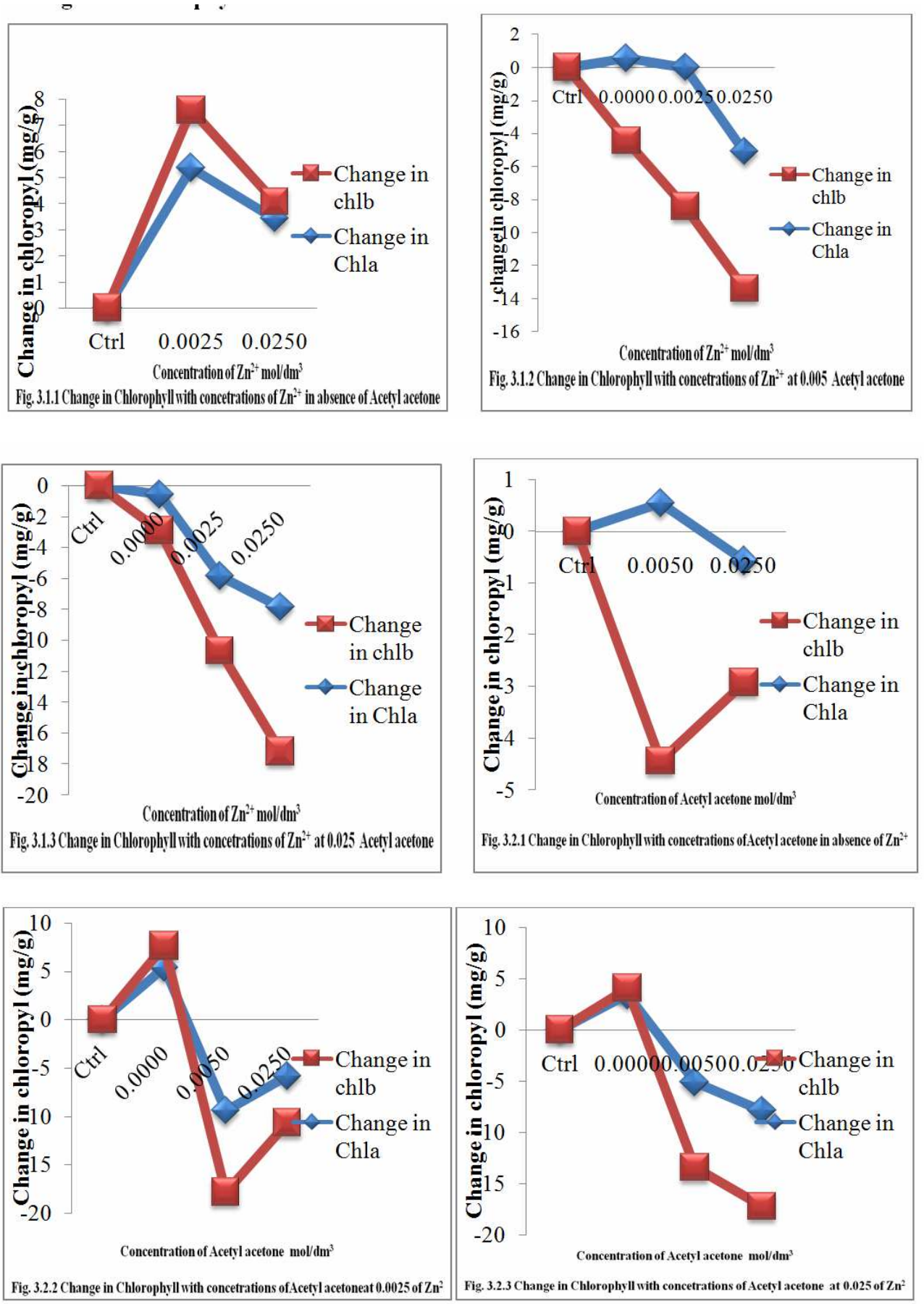
Table 3.1C. ANOVA output for changes in chlorophyll a and chlorophyll $b$.

\begin{tabular}{|c|c|c|c|c|c|c|}
\hline Parameter & Source & DF & SS & MS & $\mathbf{F}$ & P-value \\
\hline \multirow{6}{*}{$\begin{array}{c}\Delta \mathrm{chl} \text { a and } \\
\mathrm{b}\end{array}$} & $\begin{array}{c}\mathrm{Zn}^{2+} \\
+ \\
0.000 \mathrm{AA}\end{array}$ & 2 & 13.41458 & 6.70729 & 2.307729 & 0.180567 \\
\hline & $\begin{array}{c}\Delta \mathrm{Zn}^{2+} \\
+ \\
0.005 \mathrm{AA} \\
\end{array}$ & 2 & 100.0229 & 50.01145 & 2.894997 & 0.106963 \\
\hline & $\begin{array}{c}\Delta \mathrm{Zn}^{2+} \\
+ \\
0.025 \mathrm{AA}\end{array}$ & 2 & 40.27132 & 20.13566 & 1.945457 & 0.198525 \\
\hline & $\begin{array}{c}\mathrm{AA} \\
+ \\
0.000 \mathrm{Zn}^{2+}\end{array}$ & 2 & 11.98614 & 5.99307 & 2.753551 & 0.141761 \\
\hline & $\begin{array}{c}\Delta \mathrm{AA} \\
+ \\
0.0025 \mathrm{Zn}^{2+}\end{array}$ & 2 & 18.47028 & 9.235138 & 0.424553 & 0.666508 \\
\hline & $\begin{array}{c}\Delta \mathrm{AA} \\
+ \\
0.025 \mathrm{Zn}^{2+}\end{array}$ & 2 & 36.38524 & 18.19262 & 1.016237 & 0.400003 \\
\hline
\end{tabular}

Abbreviations: $\Delta \mathrm{AA}=$ change in concentration of acetyl acetone, $\Delta \mathrm{chl}=$ change in chlorophyll, $\Delta \mathrm{Zn}^{2+}=$ change in concentration of zinc

Table 3.1C shows the changes in chlorophyll (a) and chlorophyll (b).

Figure 3.1.1 shows the changes in chlorophyll (a) and chlorophyll (b). The change in plant chlorophyll (a) and chlorophyll (b) for all treatments including the control was determined by comparing with the corresponding control value. Concentration of $\mathrm{Zn}^{2+}$ was varied from $0.000,0.0025$ and $0.025 \mathrm{~mol} \mathrm{dm}^{-3}$ in the absence of acetyl acetone, addition of $0.0025 \mathrm{~mol} \mathrm{dm}^{-3} \mathrm{Zn}^{2+}$ causes the chlorophyll (a) and the chlorophyll (b) to increases, further addition of $\mathrm{Zn}^{2+}$ concentration to $0.025 \mathrm{~mol} / \mathrm{dm}^{3}$ decreases the chlorophyll (a) and (b) content. Changes in chlorophyll (a) and chlorophyll (b) contents of the plant in the absence of acetyl acetone were insignificant ( $p>0.05$ ).

Figure 3.1.2 shows the changes in chlorophyll (a) and chlorophyll (b), concentration of $\mathrm{Zn}^{2+}$ was varied from $0.000,0.0025$ and $0.025 \mathrm{~mol} \mathrm{dm}^{-3}$ at $0.0050 \mathrm{~mol} \mathrm{dm}^{-3}$ acetyl acetone. At $0.000 \mathrm{~mol} \mathrm{dm}^{-3} \mathrm{Zn}^{2+}$, there was slightly increase in the chlorophyll (a) and subsequent decrease in the chlorophyll (b), addition of $0.0025 \mathrm{~mol} \mathrm{dm}^{-3}$ causes slightly decrease in the chlorophyll (a) and chlorophyll (b) also decrease, further addition of $\mathrm{Zn}^{2+}$ 
to $0.025 \mathrm{~mol} \mathrm{dm}^{-3}$ decreases the content of chlorophyll (a) and (b). Changes in chlorophyll (a) and chlorophyll (b) contents of the plant at $0.0050 \mathrm{~mol} \mathrm{dm}^{-3}$ of acetyl acetone were insignificant $(\mathrm{p}>0.05)$.

Figure 3.1.3 shows the changes in chlorophyll (a) and chlorophyll (b), concentration of $\mathrm{Zn}^{2+}$ was varied from $0.000,0.0025$ and $0.025 \mathrm{~mol} \mathrm{dm}^{-3}$ at $0.025 \mathrm{~mol} \mathrm{dm}^{-3}$ acetyl acetone. At $0.000 \mathrm{~mol} \mathrm{dm}^{-3} \mathrm{Zn}^{2+}$ causes decrease in chlorophyll (a) and (b), addition of $0.0025 \mathrm{~mol} \mathrm{dm}^{-3}$ decreases the chlorophyll (a) and (b), further addition of $\mathrm{Zn}^{2+}$ to 0.025 mol dm${ }^{-3}$ decreases the chlorophyll (a) and (b) content. Changes in chlorophyll (a) and chlorophyll (b) contents of the plant at $0.0250 \mathrm{~mol} \mathrm{dm}^{-3}$ of acetyl acetone were insignificant $(\mathrm{p}>0.05)$.

Figure 3.2.1 shows the changes in chlorophyll (a) and chlorophyll (b), with concentration of acetyl acetone in the absence of $\mathrm{Zn}^{2+}$. Addition of $0.005 \mathrm{~mol} \mathrm{dm}^{-3}$ acetyl acetone increases the chlorophyll (a) and chlorophyll (b) decreases drastically, further addition of $0.025 \mathrm{~mol} \mathrm{dm}^{-3}$ acetyl acetone decreases the content of both the chlorophyll (a) and (b). Changes in chlorophyll (a) and chlorophyll (b) contents of the plant in the absence of $\mathrm{Zn}^{2+}$ were insignificant $(\mathrm{p}>0.05)$.

Figure 3.2.2 shows the changes in chlorophyll (a) and chlorophyll (b), with concentration of acetyl acetone at $0.0025 \mathrm{~mol} \mathrm{dm}^{-3} \mathrm{Zn}^{2+}$. At $0.000 \mathrm{~mol} \mathrm{dm}^{-3}$ acetyl acetone, increases but chlorophyll (a) and chlorophyll (b), addition of $0.025 \mathrm{~mol} \mathrm{dm}^{-3}$ acetyl acetone decreases the chlorophyll (a) and (b), further addition of $0.0025 \mathrm{~mol} \mathrm{dm}^{-3}$ acetyl acetone increases but chlorophyll (a) and chlorophyll (b). Changes in chlorophyll (a) and chlorophyll (b) contents of the plant at $0.0025 \mathrm{~mol} \mathrm{dm}^{-3}$ of $\mathrm{Zn}^{2+}$ were insignificant $(\mathrm{p}>0.05)$.

Figure 3.2.3 shows the changes in chlorophyll (a) and chlorophyll (b), with concentration of acetyl acetone at $0.025 \mathrm{~mol} \mathrm{dm}^{-3} \mathrm{Zn}^{2+}$. At $0.000 \mathrm{~mol} \mathrm{dm}^{-3} \mathrm{Zn}^{2+}$ with different concentration of acetyl acetone gives an increase of chlorophyll (a) and (b), at $0.000 \mathrm{~mol} \mathrm{dm}^{-3}$ acetyl acetone results in decrease of chlorophyll (a) and (b), further addition of $0.025 \mathrm{~mol} \mathrm{dm}^{-3}$ acetyl acetone maintained the decrease of the chlorophyll (a) and (b) contents Changes in chlorophyll (a) and chlorophyll (b) contents of the plant at $0.025 \mathrm{~mol} \mathrm{dm}^{-3}$ of $\mathrm{Zn}^{2+}$ were insignificant ( $\mathrm{p}>0.05$ ). 


\section{Changes in Carotenoid}
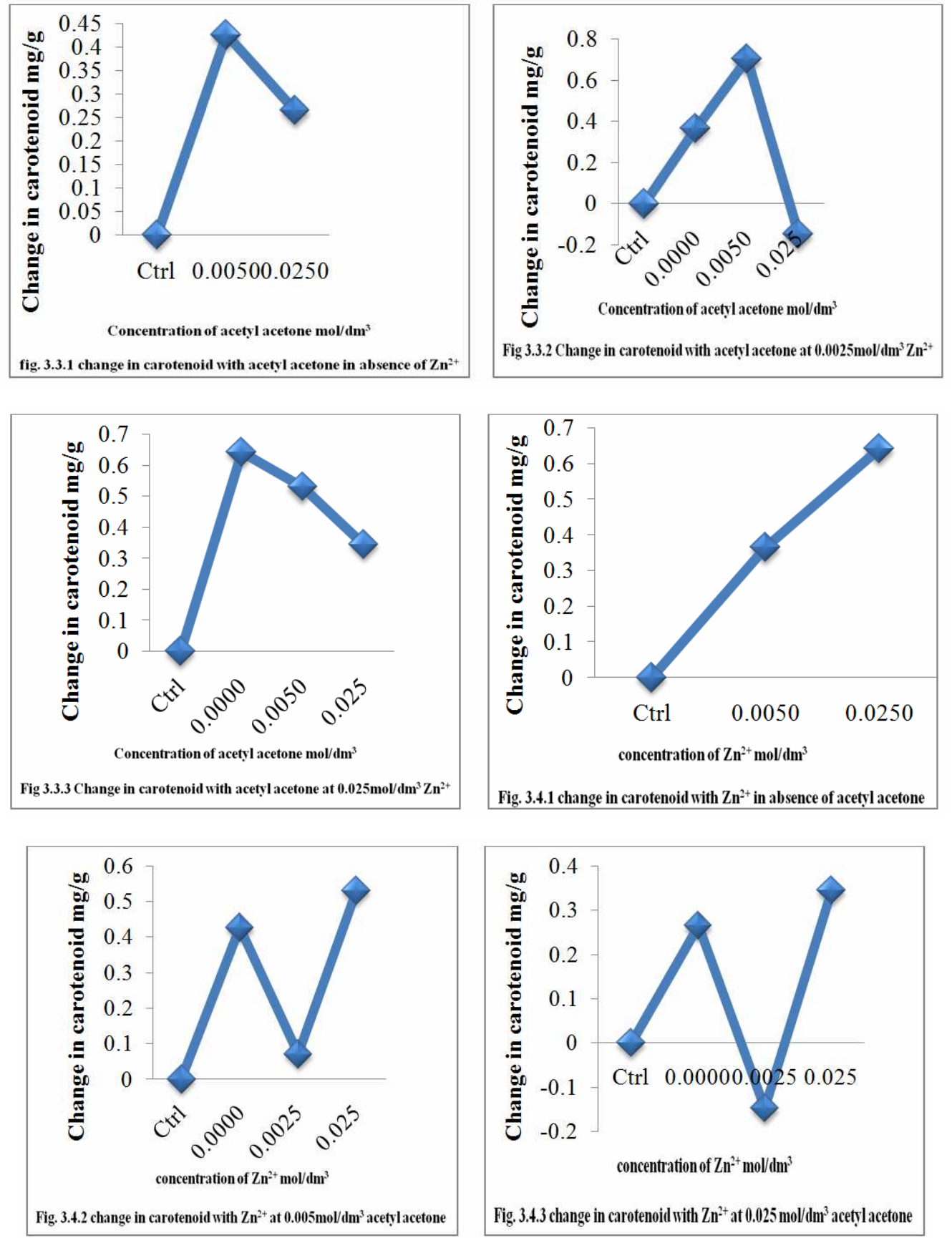
Table 3.1D. ANOVA output for changes in carotenoid.

\begin{tabular}{|c|c|c|c|c|c|c|}
\hline Parameter & \begin{tabular}{c} 
Source \\
\hline \multirow{10}{*}{$\begin{array}{c}\Delta \mathrm{Zn}^{2+} \\
+ \\
0.000 \mathrm{AA}\end{array}$}
\end{tabular} & 1 & 0.109207 & 0.109207 & 16.57388 & 0.055372 \\
\cline { 2 - 7 } & $\begin{array}{c}\Delta \mathrm{Zn}^{2+} \\
+ \\
0.005 \mathrm{AA}\end{array}$ & 1 & 0.13207 & 0.13207 & 1.438785 & 0.296527 \\
\cline { 2 - 7 } & $\begin{array}{c}\Delta \mathrm{Zn}^{2+} \\
+ \\
0.025 \mathrm{AA}\end{array}$ & 1 & 0.369024 & 0.369024 & 32.38833 & 0.004708 \\
\cline { 2 - 7 } & $\begin{array}{c}\Delta \mathrm{AA} \\
+ \\
0.000 \mathrm{Zn}\end{array}$ & 1 & 0.239317 & 0.239317 & 12.42552 & 0.071907 \\
\cline { 2 - 7 } & $\begin{array}{c}\Delta \mathrm{AA} \\
+ \\
0.0025 \\
\mathrm{Zn}^{2+}\end{array}$ & 1 & 0.16642 & 0.16642 & 5.698143 & 0.075407 \\
\cline { 2 - 7 } & $\begin{array}{c}\Delta \mathrm{AA} \\
+ \\
0.025 \mathrm{Zn}^{2+}\end{array}$ & 1 & 0.031435 & 0.031435 & 0.896088 & 0.397434 \\
\hline
\end{tabular}

Abbreviations: $\Delta \mathrm{AA}=$ change in concentration of acetyl acetone, $\Delta \mathrm{crtnd}=$ change in Carotenoid, $\Delta \mathrm{Zn} 2+=$ change in concentration of zinc

Table 3.1D shows the changes in carotenoid.

Figure 3.3.1 shows the changes in carotenoid, with concentration of acetyl acetone in the absence of $\mathrm{Zn}^{2+}$. The change in plant carotenoid for all treatments including the control was determined by comparing with the corresponding control value. Addition of $0.005 \mathrm{~mol} \mathrm{dm}^{-3}$ acetyl acetone increases the carotenoid content drastically, further addition of $0.025 \mathrm{~mol} \mathrm{dm}^{-3}$ acetyl acetone causes decrease of carotenoid content. Changes in carotenoid contents of the plant due to the absence of $\mathrm{Zn}^{2+}$ were insignificant $(\mathrm{p}>0.05)$.

Figure 3.3.2 shows the changes in carotenoid, with concentration of acetyl acetone at $0.0025 \mathrm{~mol} \mathrm{dm}^{-3} \mathrm{Zn}^{2+}$. At $0.000 \mathrm{~mol} \mathrm{dm}^{-3}$ acetyl acetone, the carotenoid content increases, addition of $0.005 \mathrm{~mol} \mathrm{dm}^{-3}$ acetyl acetone, carotenoid increases, further addition of $0.025 \mathrm{~mol} \mathrm{dm}^{-3}$ acetyl acetone carotenoid decreases. Changes in carotenoid contents of the plant at $0.0025 \mathrm{~mol} \mathrm{dm}{ }^{-3} \mathrm{Zn}^{2+}$ were insignificant $(\mathrm{p}>0.05)$. 
Figure 3.3.3 shows the changes in carotenoid, with concentration of acetyl acetone at $0.0250 \mathrm{~mol} \mathrm{dm}^{-3} \mathrm{Zn}^{2+}$. At $0.000 \mathrm{~mol} \mathrm{dm}^{-3}$ of acetyl acetone the carotenoid content increases, subsequent addition of $0.005 \mathrm{~mol} \mathrm{dm}^{-3}$ and $0.025 \mathrm{~mol} \mathrm{dm}^{-3}$ of acetyl acetone decreases the carotenoid content. Changes in carotenoid contents of the plant at 0.025 mol dm ${ }^{-3} \mathrm{Zn}^{2+}$ were significant $(\mathrm{p}<0.05)$.

Figure 3.4.1 shows the changes in carotenoid, with concentrations of $\mathrm{Zn}^{2+}$ in the absence of acetyl acetone. Addition of $0.005 \mathrm{~mol} \mathrm{dm}^{-3} \mathrm{Zn}^{2+}$ increases the carotenoid content, further addition of $0.025 \mathrm{~mol} \mathrm{dm}^{-3} \mathrm{Zn}^{2+}$ increases the carotenoid content. Changes in carotenoid contents of the plant due to the absence of acetyl acetone were insignificant $(\mathrm{p}>0.05)$.

Figure 3.4.2 shows the changes in carotenoid, with concentration of $\mathrm{Zn}^{2+}$ at 0.005 mol dm${ }^{-3}$ of acetyl acetone. Addition of $0.000 \mathrm{~mol} \mathrm{dm}^{-3} \mathrm{Zn}^{2+}$ increases the carotenoid content, addition of $0.0025 \mathrm{~mol} \mathrm{dm}{ }^{-3} \mathrm{Zn}^{2+}$ decreases the carotenoid, further addition of $0.025 \mathrm{Zn}^{2+}$ increases the carotenoid content. Changes in carotenoid contents of the plant at $0.005 \mathrm{~mol} \mathrm{dm}^{-3}$ acetyl acetone were insignificant $(\mathrm{p}>0.05)$.

Figure 3.4.3 shows the changes in carotenoid, with concentration of $\mathrm{Zn}^{2+}$ at 0.025 mol dm${ }^{-3}$ of acetyl acetone. At $0.000 \mathrm{~mol} \mathrm{dm}^{-3} \mathrm{Zn}^{2+}$ the carotenoid content increase, addition of $0.0025 \mathrm{Zn}^{2+}$ decreases the carotenoid, and further addition of $0.025 \mathrm{~mol} \mathrm{dm}^{-3}$ $\mathrm{Zn}^{2+}$ increases the carotenoid content. Changes in carotenoid contents of the plant at $0.005 \mathrm{~mol} \mathrm{dm}^{-3}$ acetyl acetone were insignificant ( $\mathrm{p}>0.05$ ).

\section{Changes in Proline}
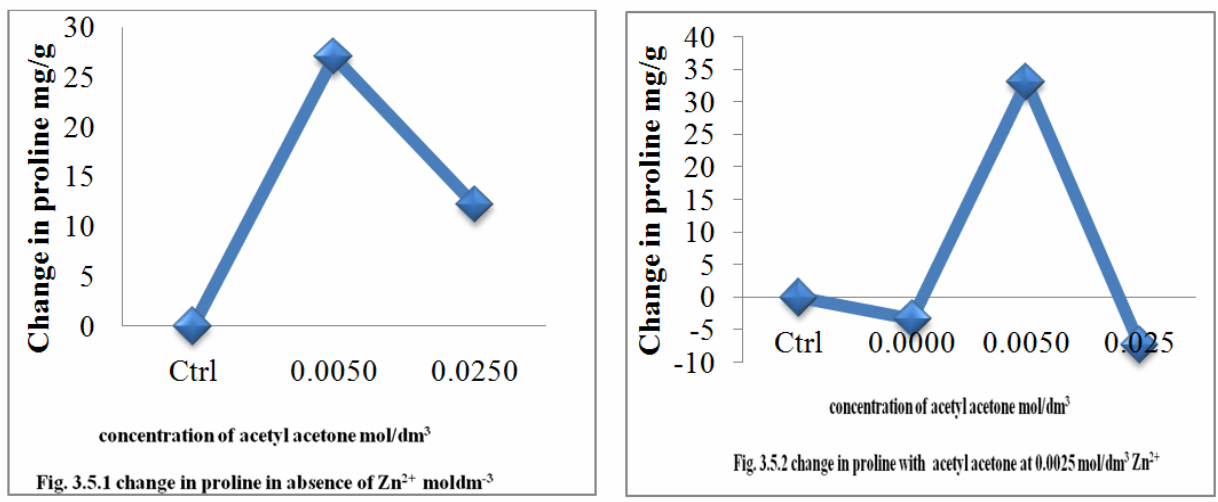

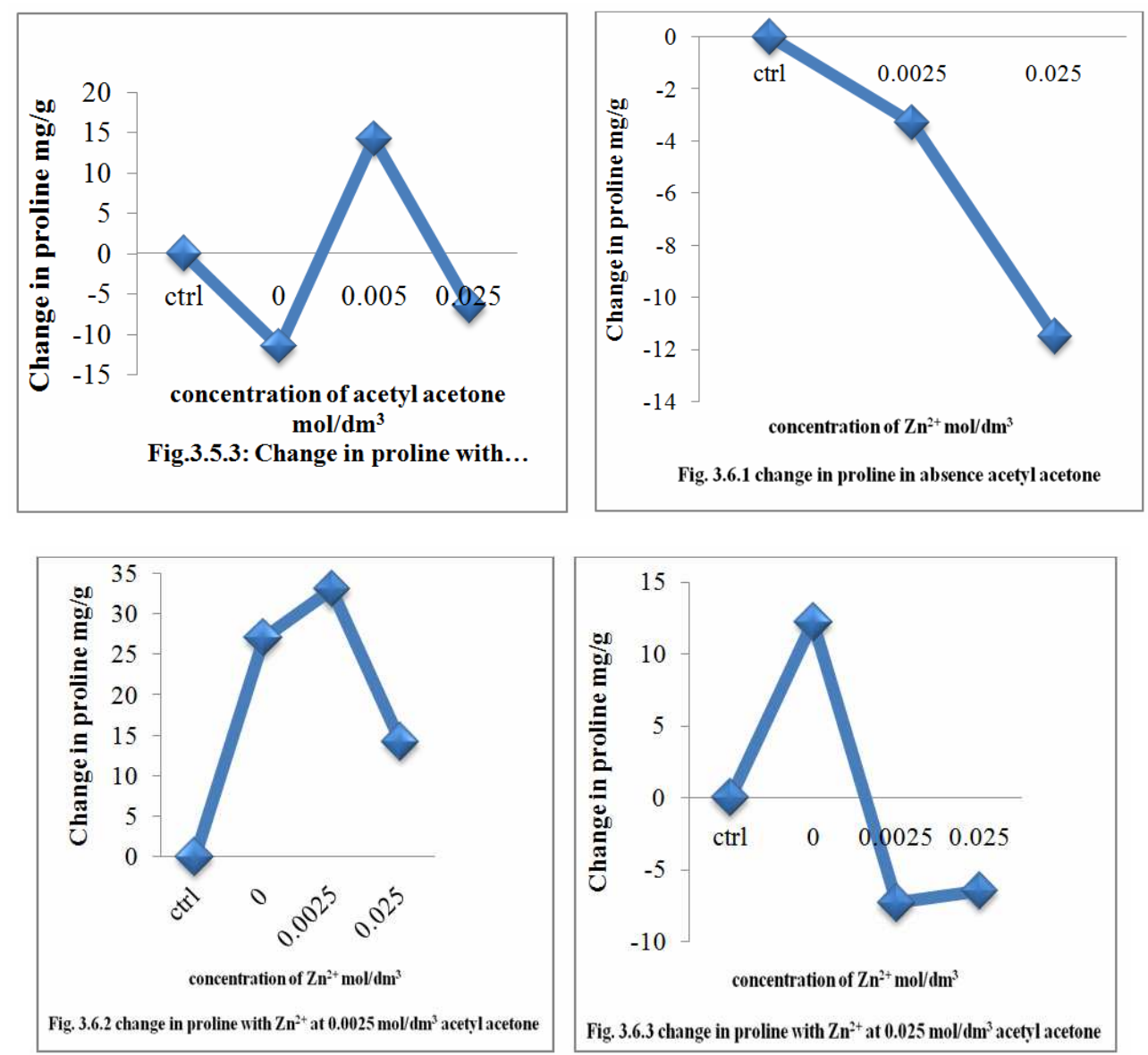

Table 3.1E. ANOVA output for changes in proline.

\begin{tabular}{|c|c|c|c|c|c|c|}
\hline Parameter & Source & $D F$ & $S S$ & $M S$ & $F$ & P-value \\
\hline \multirow[t]{4}{*}{$\Delta$ prln } & $\begin{array}{c}\Delta \mathrm{Zn}^{2+} \\
+ \\
0.000 \mathrm{AA}\end{array}$ & 1 & 0.065209 & 0.065209 & 534.9257 & 0.001864 \\
\hline & $\begin{array}{c}\Delta \mathrm{Zn}^{2+} \\
+ \\
0.005 \mathrm{AA}\end{array}$ & 1 & 0.110078 & 0.110078 & 8.897387 & 0.040624 \\
\hline & $\begin{array}{c}\Delta \mathrm{Zn}^{2+} \\
+ \\
0.025 \mathrm{AA}\end{array}$ & 1 & 0.096307 & 0.096307 & 1.744987 & 0.25701 \\
\hline & $\begin{array}{c}\Delta \mathrm{AA} \\
+ \\
0.000 \mathrm{Zn}^{2+}\end{array}$ & 1 & 0.355782 & 0.355782 & 0.743044 & 0.479536 \\
\hline
\end{tabular}




\begin{tabular}{|c|c|c|c|c|c|c|}
\hline & $\begin{array}{c}\Delta \mathrm{AA} \\
+ \\
0.0025 \mathrm{Zn}^{2+}\end{array}$ & 1 & 0.163779 & 0.163779 & 56.9637 & 0.001651 \\
\cline { 2 - 6 } & $\begin{array}{c}\Delta \mathrm{AA} \\
+ \\
0.025 \mathrm{Zn}^{2+}\end{array}$ & 1 & 0.203821 & 0.203821 & 22.99585 & 0.008677 \\
\hline
\end{tabular}

Abbreviations: $\Delta \mathrm{AA}=$ change in concentration of acetyl acetone, $\Delta$ prln $=$ change in praline, $\Delta \mathrm{Zn}^{2+}=$ change in concentration of zinc

Table 3.1E shows the changes in proline.

Figure 3.5.1 shows the changes in proline, with concentration of acetyl acetone in the absence of $\mathrm{Zn}^{2+}$. The change in plant proline for all treatments including the control was determined by comparing with the corresponding control value. Addition of 0.005 mol dm${ }^{-3}$ acetyl acetone increases the proline, further addition of $0.025 \mathrm{~mol} \mathrm{dm}^{-3}$ acetyl acetone causes decrease of proline content. Changes in proline contents of the plant due to the absence of $\mathrm{Zn}^{2+}$ were significant $(\mathrm{p}<0.05)$.

Figure 3.5.2 shows the changes in proline, with concentration of acetyl acetone at $0.0025 \mathrm{~mol} \mathrm{dm}^{-3} \mathrm{Zn}^{2+}$. At $0.000 \mathrm{~mol} \mathrm{dm}^{-3}$ acetyl acetone the proline decrease, addition of $0.005 \mathrm{~mol} \mathrm{dm}^{-3}$ acetyl acetone the proline increase, further addition of $0.025 \mathrm{~mol} \mathrm{dm}^{-}$ 3 acetyl acetone, the proline content decreases. Changes in proline contents of the plant at $0.0025 \mathrm{~mol} \mathrm{dm}^{-3} \mathrm{Zn}^{2+}$ were significant $(\mathrm{p}<0.05)$.

Figure 3.5.3 shows the changes in proline, with concentration of acetyl acetone at $0.025 \mathrm{Zn}^{2+}$. At $0.000 \mathrm{~mol} \mathrm{dm}^{-3}$ of acetyl acetone the proline decreases. Addition of $0.005 \mathrm{~mol} \mathrm{dm}^{-3}$ increases the proline content, further addition of $0.025 \mathrm{~mol} \mathrm{dm}^{-3}$ acetyl acetone decreases the proline. Changes in proline contents of the plant at $0.025 \mathrm{~mol}$ $\mathrm{dm}^{-3} \mathrm{Zn}^{2+}$ were insignificantly $(\mathrm{p}>0.05)$.

Figure 3.6.1 shows the changes in proline with concentration of $\mathrm{Zn}^{2+}$ in the absence of acetyl acetone. At $0.000 \mathrm{~mol} \mathrm{dm}^{-3}$ of acetyl acetone the proline decreases. Addition of $0.0025 \mathrm{~mol} \mathrm{dm}{ }^{-3} \mathrm{Zn}^{2+}$ decreases the proline, further addition of $0.025 \mathrm{~mol} \mathrm{dm}{ }^{-3} \mathrm{Zn}^{2+}$ decreases the proline. Changes in proline contents of the plant due to the absence of acetyl acetone were insignificant $(\mathrm{p}>0.05)$. 
Figure 3.6.2 shows the changes in proline, with concentration of $\mathrm{Zn}^{2+}$ at 0.005 mol dm${ }^{-3}$ of acetyl acetone. At $0.000 \mathrm{~mol} \mathrm{dm}{ }^{-3}$ and $0.0025 \mathrm{~mol} \mathrm{dm}^{-3} \mathrm{Zn}^{2+}$, the proline content increases, further addition of $0.025 \mathrm{~mol} \mathrm{dm}^{-3} \mathrm{Zn}^{2+}$ the proline content decreases drastically. Changes in proline contents of the plant due to the absence of acetyl acetone were significant $(\mathrm{p}<0.05)$.

Figure 3.6.3 shows the changes in proline, with concentration of $\mathrm{Zn}^{2+}$ at 0.025 mol dm${ }^{-3}$ of acetyl acetone. At $0.000 \mathrm{~mol} \mathrm{dm}^{-3} \mathrm{Zn}^{2+}$ the proline content increases, addition of $0.025 \mathrm{~mol} \mathrm{dm}{ }^{-3} \mathrm{Zn}^{2+}$ decreases the proline, further addition of 0.025 mol dm ${ }^{-3} \mathrm{Zn}^{2+}$ increases in proline, Changes in proline contents of the plant at 0.005 mol dm ${ }^{-3}$ acetyl acetone were significant $(\mathrm{p}<0.05)$.

\section{Changes in Root and Shoot Zinc}

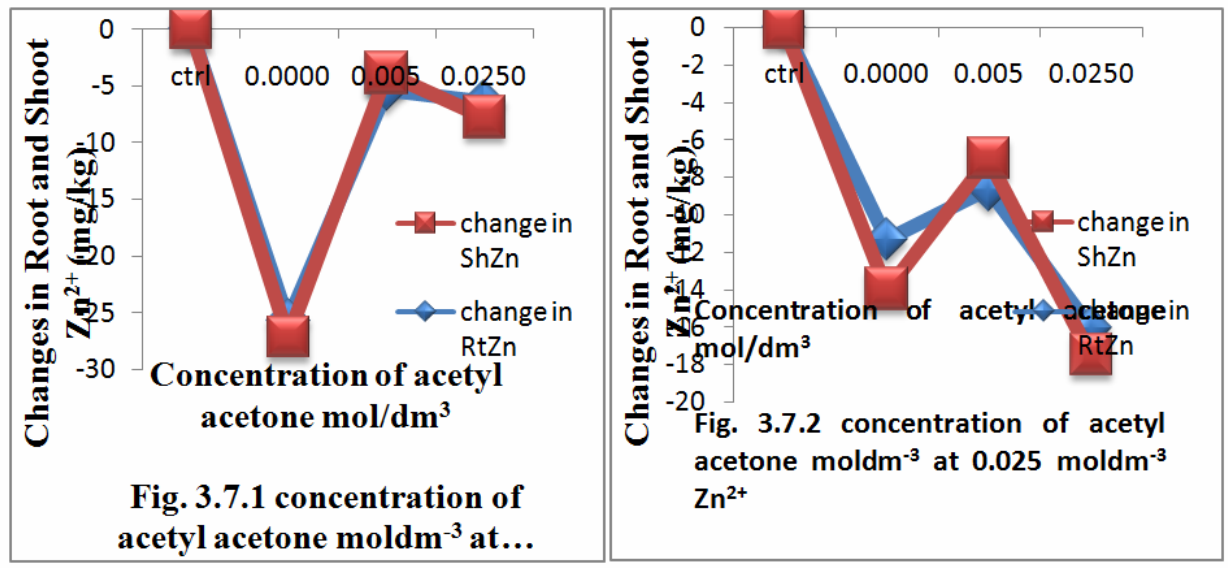

Table 3.1F. ANOVA output for shoot and root zinc.

\begin{tabular}{|c|c|c|c|c|c|c|}
\hline Parameter & Source & DF & SS & MS & F & P-value \\
\hline \multirow{2}{*}{$\begin{array}{c}\Delta \mathrm{RtZn} \text { and } \\
\Delta \mathrm{ShZn}\end{array}$} & $\begin{array}{c}\Delta \mathrm{AA} \\
+ \\
0.0025 \mathrm{Zn}^{2+}\end{array}$ & 2 & 300.3774 & 150.1887 & 3.351164 & 0.105391 \\
\hline & $\begin{array}{c}\Delta \mathrm{AA} \\
+ \\
0.0250 \mathrm{Zn}^{2+}\end{array}$ & 2 & 269.9856 & 134.9928 & 21.28785 & 0.001885 \\
\hline
\end{tabular}

Abbreviations: $\triangle \mathrm{AA}=$ change in concentration of acetyl acetone, $\Delta \mathrm{RtZn}=$ changes in root zinc, $\Delta \mathrm{Zn}^{2+}=$ change in concentration of zinc, $\Delta \mathrm{ShZn}=$ changes in Shoot zinc 
Table 3.1F shows the changes in root and shoot zinc.

Figure 3.7.1 shows the changes in root $(\Delta \mathrm{RtZn})$ and shoots $(\Delta \mathrm{ShZn})$ Zinc in Cucumber (Cucumis sativus) seedlings replanted in various hydroponic mixture. These changes were determined by subtracting the corresponding control values from the values of individual treatments. For $0.0025 \mathrm{~mol} \mathrm{dm}^{-3} \mathrm{Zn}^{2+}$ with change in concentration of acetyl acetone mol $\mathrm{dm}^{-3}, \Delta \mathrm{ShZn}$ uptake was slightly lower than that of $\Delta \mathrm{RtZn}$ at 0.000 acetyl acetone. When the concentration of acetyl acetone was increased to 0.005 mol dm${ }^{-3}$, the root and shoot $\mathrm{Zn}$ decreased. Further addition of $0.025 \mathrm{~mol} \mathrm{dm}^{-3}$ acetyl acetone slightly decreases the Zinc uptake of the shoot, and that of root maintained. Changes in root and shoot of the plant at $0.0025 \mathrm{~mol} \mathrm{dm}^{-3} \mathrm{Zn}^{2+}$ were insignificant $(\mathrm{p}>0.05)$.

Figure 3.7.2 shows the changes in root $(\Delta \mathrm{RtZn})$ and shoots $(\Delta \mathrm{ShZn}) \mathrm{Zinc}$ in Cucumber (Cucumis sativus) seedlings replanted in various hydroponic mixtures. These changes were determined by subtracting the corresponding control values from the values of individual treatments. For $0.025 \mathrm{~mol} \mathrm{dm}^{-3} \mathrm{Zn}^{2+}$ with change in concentration of acetyl acetone mol dm ${ }^{-3}, \Delta \mathrm{ShZn}$ uptake was lower than that of $\Delta \mathrm{RtZn}$ at 0.000 mol dm${ }^{-3}$ acetyl acetone. When the concentration of acetyl acetone was increased to $0.005 \mathrm{~mol} \mathrm{dm}^{-3}$, the root and shoot $\mathrm{Zn}$ decreased. Further addition of $0.025 \mathrm{~mol} \mathrm{dm}^{-3}$ acetyl acetone of the zinc uptake of but the root and that of shoot increases. Changes in root and shoot of the plant at $0.025 \mathrm{~mol} \mathrm{dm}^{-3} \mathrm{Zn}^{2+}$ were significant $(\mathrm{p}<0.05)$.

\section{Changes in Translocation Factor}

Table 3.1G. ANOVA output for change in translocation factor.

\begin{tabular}{|c|c|c|c|c|c|c|}
\hline Parameter & Source & DF & SS & MS & F & P-value \\
\hline \multirow{4}{*}{$\Delta \mathrm{TF}$} & $\begin{array}{c}\Delta \mathrm{AA} \\
+ \\
0.0025 \mathrm{Zn}^{2+}\end{array}$ & 1 & $\mathbf{0 . 0 1 8 1 9 4}$ & 0.018194 & 0.137627 & 0.729464 \\
\cline { 2 - 7 } & $\begin{array}{c}\Delta \mathrm{AA} \\
+ \\
0.0250 \mathrm{Zn}^{2+}\end{array}$ & 1 & 0.000314 & 0.000314 & 0.014404 & 0.910258 \\
\hline
\end{tabular}

Abbreviations: $\triangle \mathrm{AA}=$ change in concentration of acetyl acetone, $\Delta \mathrm{TF}=$ Change in translocation factor, $\Delta$ $\mathrm{Zn}^{2+}=$ change in concentration of zinc 
Table 3.1G shows the changes in translocation factor.

Figure 3.8.1 shows the changes in $\mathrm{Zn}^{2+}$ translocation factor in Cucumber (Cucumis sativus) seedlings replanted in various hydroponic mixtures. Zinc translocation factor (TF) is defined as ratio of shoot to root concentration of zinc (Adriano [1]).

The changes in translocation factor $(\Delta \mathrm{TF})$ were determined by subtracting the corresponding control values from the values of individual treatments. For 0.0025 mol dm${ }^{-3} \mathrm{Zn}^{2+}$ with $0.000 \mathrm{~mol} \mathrm{dm}^{-3}$, acetyl acetone change in translocation factor increased. When the concentration of acetyl acetone was increased to $0.005 \mathrm{~mol} \mathrm{dm}^{-3}$, the translocation factor decreased, further addition of $0.025 \mathrm{~mol} \mathrm{dm}^{-3}$ acetyl acetone causes the decrease of the translocation factor. These changes in translocation factor at $0.0025 \mathrm{~mol} \mathrm{dm}^{-3}$ were insignificant $(\mathrm{p}>0.05)$.

Figure 3.8.2 shows the changes in $\mathrm{Zn}^{2+}$ translocation factor in Cucumber (Cucumis sativus) seedlings replanted in various hydroponic mixtures. For $0.0025 \mathrm{~mol} \mathrm{dm}{ }^{-3} \mathrm{Zn}^{2+}$ with $0.000 \mathrm{~mol} \mathrm{dm}^{-3}$, acetyl acetone change in translocation factor decreased. When the concentration of acetyl acetone was increased to $0.005 \mathrm{~mol} \mathrm{dm}^{-3}$, the change in translocation factor increases, further addition of $0.025 \mathrm{~mol} \mathrm{dm}^{-3}$ acetyl acetone caused a serious increase of the translocation factor. These changes in translocation factor at $0.025 \mathrm{~mol} \mathrm{dm}^{-3}$ were insignificant ( $\mathrm{p}>0.05$ ).

\section{Changes in pH of Hydroponics}

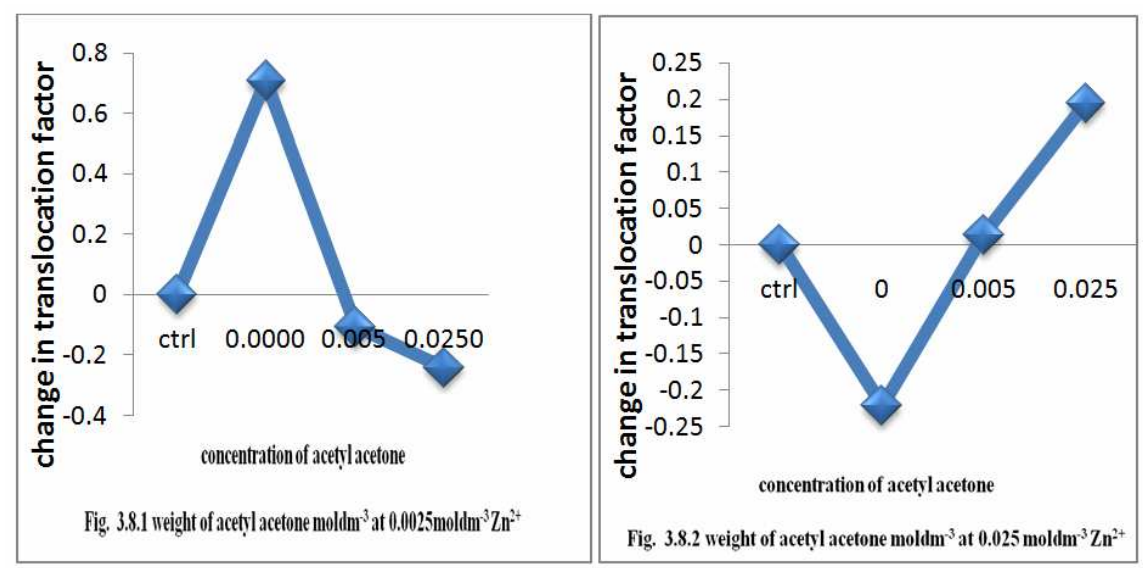


Table 3.1H. ANOVA Output for changes in hydroponic pH.

\begin{tabular}{|c|c|c|c|c|c|c|}
\hline Parameter & Source & DF & SS & MS & $\mathbf{F}$ & P-value \\
\hline \multirow{2}{*}{$\begin{array}{c}\Delta \mathrm{pHBP} \text { and } \\
\Delta \mathrm{pHAH}\end{array}$} & $\begin{array}{c}\mathrm{AA} \\
+ \\
0.0025 \mathrm{Zn}^{2+}\end{array}$ & 2 & 0.100716 & 0.050358 & 90.17713 & 3.34E-05 \\
\hline & $\begin{array}{c}\Delta \mathrm{AA} \\
+ \\
0.0250 \mathrm{Zn}^{2+}\end{array}$ & 2 & 99.92982 & 49.96491 & 210.3034 & $2.78 \mathrm{E}-06$ \\
\hline
\end{tabular}

Abbreviations: $\triangle \mathrm{AA}=$ change in concentration of acetyl acetone, $\Delta \mathrm{pHBP}=$ change in $\mathrm{pH}$ before replanting, $\Delta \mathrm{Zn}^{2+}=$ change in concentration of zinc, $\Delta \mathrm{pHAH}=$ change in $\mathrm{pH}$ after harvest

Table $3.1 \mathrm{H}$ shows changes in hydroponic $\mathrm{pH}$.

Figure 3.9.1 shows the changes in $\mathrm{pH}$ of hydroponic mixtures before planting $(\triangle \mathrm{pHBP})$ and after harvest $(\triangle \mathrm{pHAH})$. They were determined by subtracting the corresponding control values from the values of individual treatments. A negative value indicates that the $\mathrm{pH}$ of a treatment is less than the control $\mathrm{pH}$. Changes in $\mathrm{pH}$ before planting and after harvest were zero for control. When the concentration of $\mathrm{Zn}^{2+}$ is $0.0025 \mathrm{~mol} \mathrm{dm}^{-3}$, then the $\mathrm{pH}$ before planting increased with increase in the concentration of acetyl acetone from $0.000,0.005$ and $0.025 \mathrm{~mol} \mathrm{dm}^{-3}$. When the concentration of $\mathrm{Zn}^{2+}$ is $0.0025 \mathrm{~mol} \mathrm{dm}{ }^{-3}$, the $\mathrm{pH}$ after harvest slightly decreased with increase in the concentration of acetyl acetone from 0.000 and 0.005 further addition of $0.025 \mathrm{~mol} \mathrm{dm}^{-3}$ acetyl acetone increased the $\mathrm{pH}$ of but before planting and after harvest. These changes in $\mathrm{pH}$ before planting and after harvest at $0.0025 \mathrm{~mol} \mathrm{dm}^{-3}$ are insignificant $(\mathrm{p}>0.05)$.

Figure 3.9.2 shows the changes in $\mathrm{pH}$ of hydroponic mixtures before planting $(\triangle \mathrm{pHBP})$ and after harvest $(\Delta \mathrm{pHAH})$. When the concentration of $\mathrm{Zn}^{2+}$ is $0.0025 \mathrm{~mol}$ $\mathrm{dm}^{-3}$, the $\mathrm{pH}$ before planting and after harvest increased at $0.000 \mathrm{~mol} \mathrm{dm}^{-3}$ of acetyl acetone, further addition of $0.005 \mathrm{~mol} \mathrm{dm}^{-3}$ acetyl acetone caused a slightly decrease in $\mathrm{pH}$ before planting and after harvest, the slightly decrease was maintained after the addition of $0.025 \mathrm{~mol} \mathrm{dm}^{-3}$ acetyl acetone. These changes in $\mathrm{pH}$ before planting and after harvest at $0.025 \mathrm{~mol} \mathrm{dm}^{-3}$ are insignificant ( $\mathrm{p}>0.05$ ). 


\section{Discussion}

Various abiotic stresses decrease the chlorophyll content in plants (Ahmad et al. [2]); It was shown that the plants treated with $\mathrm{Zn}$ exhibited inhibitory effect with respect to chlorophyll (a) chlorophyll (b) and carotenoid contents at high concentrations of $\mathrm{Zn}$ compared with controls. At low concentration of $\mathrm{Zn}$ the chlorophyll (a), chlorophyll (b) and carotenoid contents increased. Copper was more toxic than $\mathrm{Zn}$ in terms of chlorophyll inhibition. The present result showed decrease in chlorophyll content corroborated with the findings of (Bassi and Sharma [3]); who found that Copper was more toxic than $\mathrm{Zn}$ in terms of chlorophyll inhibition in cucumber seedlings. The losses in chlorophyll content can consequently lead to disruption of photosynthetic machinery. Further increase in zinc level significantly decreased the chlorophyll and corotenoid content. The increased chlorophyll and carotenoid content was obviously due to zinc at low-level act as a structural and catalytic components of proteins, enzymes and as cofactors for normal development of pigment biosynthesis. The excess zinc treatment brought about a marked depression in photosynthetic pigment in plants (Manivasagaperumal et al. [24]);

The first symptom of $\mathrm{Zn}$ toxicity is a general chlorosis of the younger leaves (Herren and Feller [13]); (Fontes and Cox [9]). Increased concentration of $\mathrm{Zn}$ causes changes in plant growth parameter as reported by (Fosmire [10]); that excess zinc can be harmful and cause zinc toxicity. $\mathrm{Zn}^{2+}$ and $0.000,0.005,0.025 \mathrm{~mol} \mathrm{dm}^{-3}$ acetyl acetone to the various hydroponic mixtures in which Cucumis sativus seedlings were replanted affected the chlorophyll (a) and chlorophyll (b), carotenoid, proline, time of harvest, $\mathrm{pH}$ of the solutions, concentrations of $\mathrm{Zn}$ in root and shoot, translocation factor and weight of plant, volume of solution, Number of falling leaves. The plants were harvested when they died. Those planted in treated hydroponics died earlier than control seedlings. This could be due to that excess zinc. The weights of plants harvested in all treatment were found to decrease. According to (Wolt [43]), absorbed zinc resulted in reduction in growth rate of roots and change in branching pattern. Several workers have reported the inhibition of root grow that $1 \mu \mathrm{M}$ to $1 \mathrm{cM} \mathrm{Zn}$ or at a soil $\mathrm{Zn}$ content of $10 \mu \mathrm{gg}^{1}$. A considerable decrease in dry weights of plant parts is observed under $\mathrm{Zn}$ treatment (Richards et al. [34]).

Leaf fall was observed during the growth of seedlings. This could be due to the concentration of $\mathrm{Zn}^{2+}\left(0.000-0.025 \mathrm{~mol} \mathrm{dm}^{-3}\right)$ and acetyl acetone $(0.000-0.250$ 
mol $\mathrm{dm}^{-3}$ ). The toxic effects of heavy metals on plants depend largely on the metal concentrations in the nutrient solution (Rashid et al. [33]); As reported by (Laurie and Manthey [22]), acetyl acetone a chelating agent, forms a Zn-AA complex at $\mathrm{pH} 5.2$ to $\mathrm{pH}$ 7.7. Increasing the concentration of acetyl acetone favours the formation of the complex.

Uptake of metals into plant roots is a complex process involving transfer of metals from the soil solution to the root surface and inside the root cells. Understanding of uptake processes is hampered by the complex nature of the rhizosphere, which is in continual dynamic change interacted upon by plant roots, the soil solution composing it and microorganisms living within the rhizosphere (Laurie and Manthey [22]);

Zinc translocation to root xylem occurs via symplast and apoplast (Brennan [4]); (Broadley et al. [5]); but high level of zinc have also been phloem, denoting that this metal is translocated both through xylem and phloem tissues (Pearson et al. [29]);

\section{Conclusion}

The addition of 0.000 to $0.025 \mathrm{~mol} \mathrm{dm}^{-3} \mathrm{Zn}^{2+}$ and 0.000 to $0.250 \mathrm{~mol} \mathrm{dm}^{-3}$ acetyl acetone to various hydroponic solutions affected the growth of replanted Cucumber (Cucumis sativus) seedlings. Seedlings replanted in treated solutions died earlier than those replanted in control. The weights of harvested plants, volume of hydroponic solutions, chlorophyll (a), chloroppyll (b) and carotenoid decreased due to the toxicity of zinc. The rate and extent of translocation of zinc within the plants depended on the concentrations of $\mathrm{Zn}^{2+}$ and acetyl acetone in the hydroponic mixtures. The highest concentration of zinc taken up by the root over the control was about $400 \mathrm{mg} / \mathrm{kg}$. This was obtained from the seedlings replanted in hydroponic solution containing 0.0025 mol dm${ }^{-3} \mathrm{Zn}^{2+}$ and $0.000,0.005$ and $0.025 \mathrm{~mol} \mathrm{dm}^{-3}$ acetyl acetone. The highest concentration of $\mathrm{Zn}^{2+}$ in the shoot was about $400 \mathrm{mg} / \mathrm{kg}$ and that of root was about $150 \mathrm{mg} / \mathrm{kg}$. This was obtained from the seedling grown in hydroponic containing 0.025 mol dm ${ }^{-3} \mathrm{Zn}^{2+}$ and 0.000, 0.005 and $0.025 \mathrm{~mol} \mathrm{dm}^{-3}$ acetyl acetone.

\section{References}

[1] D. C. Adriano, Trace Element in Terrestrial Environments: Biogeochemistry, Bioavailability and Risks of Metals, 2nd ed., Springer New York, 2001, pp. 525-675. http://dx.doi.org/10.1007/978-0-387-21510-5 
[2] P. Ahmad, S. Sharma and P.S. Srivastava, In vitro selection of $\mathrm{NaHCO}_{3}$ tolerant cultivars of Morus alba (Local and Sujanpuri) in response to morphological and biochemical parameters, Hort. Sci. (Prague) 34 (2007), 114-122.

https://doi.org/10.17221/1889-HORTSCI

[3] R. Bassi and S. S. Sharma, Proline accumulation in wheat seedlings exposed to zinc and copper, Phytochemistry 33 (1993), 1339-1342.

https://doi.org/10.1016/0031-9422(93)85086-7

[4] R. F. Brennan, Zinc application and its availability to plants, Ph. D. Dissertation, School of Environmental Science, Division of Science and Engineering, Murdoch University, 2005.

[5] M. R. Broadley, P. J. White, J. P. Hammond, I. Zelko and A. Lux, Zinc in plants, New Phytol. 173 (2007), 677-703. https://doi.org/10.1111/j.1469-8137.2007.01996.x

[6] W. Caminate and J.-U. Grabow, The $C_{2 V}$ Structure of enolic acetylacetone, J. Amer. Chem. Soc. 128(3) (2006), 854-857. https://doi.org/10.1021/ja055333g

[7] James S. Douglas, Hydroponics, 5th ed., Bombay: Oxford UP, 1975.

[8] J. Emsley, Zinc, Nature's Building Blocks: An A-Z Guide to the Elements, Oxford, England, UK: Oxford University Press, 2001, pp. 499-505.

[9] R. L. F. Fontes and F. R. Cox, Effects of sulfur supply on soybean plants exposed to zinc toxicity, Journal of Plant Nutrition 18 (1995), 1893-1906.

https://doi.org/10.1080/01904169509365031

[10] G. J. Fosmire, Zinc toxicity, Am. J. Clin. Nutr. 51 (1990), 225-227. https://doi.org/10.1093/ajcn/51.2.225

[11] N. N. Greenwood and A. Earnshaw, Chemistry of the Elements, 2nd ed., Oxford: Butterworth Heinemann, 1997.

[12] K. M. Hambidge and N. F. Krebs, Zinc deficiency: A special challenge, J. Nutr. 137 (2007), 1101-1105. https://doi.org/10.1093/jn/137.4.1101

[13] T. Herren and U. Feller, Effect of locally increased zinc contents on zinc transport from the flag leaf lamina to the maturing grains of wheat, Journal of Plant Nutrition 19 (1996), 379-387. https://doi.org/10.1080/01904169609365128

[14] Alan G. Heath, Water Pollution and Fish Physiology, Boca Raton, Florida: CRC Press, 1995 , p. 57.

[15] Wolfgang A. Hellmann, Synthetic Method of Organometallic and Inorganic Chemistry: Catalysis, 2002. https://doi.org/10.1055/b-003-108610 
[16] C. A. Heyneman, Zinc deficiency and taste disorders, Ann. Pharmacother. 30 (1996), 186-187. https://doi.org/10.1177/106002809603000215

[17] J. R. Hunt, Bioavailability of iron, zinc and other trace minerals from vegetarian diets, Am. J. Clin. Nutr. 78(3) (2003), 633S-639S. https://doi.org/10.1093/ajcn/78.3.633S

[18] Institute of Medicine, Food and Nutrition Board, Dietary Reference Intakes for Vitamin K, Arsenic, Boron, Chromium, Copper, Iodine, Iron, Manganese, Molyldenum, Nickel, Silicon, Vanadium and Zinc, Washington, DC: Nation Academy Press, 2001.

[19] B. W. Jafek, M. R. Linschoten, B. W. Murrow, Anosmia after intranasal zinc gluconate use, Am. J. Rhinol. 18 (2004), 137-141. https://doi.org/10.1177/194589240401800302

[20] M. H. Jensen and W. L. Collins, Hydroponic vegetable production, Horticulture Reviews 7 (2011), 483-558. https://doi.org/10.1002/9781118060735.ch10

[21] Kimberly A. Manbeck, Nicholas C. Boaz, Nathaniel C. Bair, Allix M. S. Sanders and Anderson L. Marsh, Substituent effects on Keto-Enol equilibria using NMR spectroscopy, J. Chem. Educ. 88(10) (2011), 1444-1445. https://doi.org/10.1021/ed1010932

[22] S. H. Laurie and J. A. Manthey, The chemistry and role of metal ion chelation in plant uptake processes, in: Biochemistry of Metal Micronutrients in the Rhizosphere, Lewis Publishers, Boca Raton, 1994, 165-182.

[23] R. S. Lehto, Zinc, in: The Encyclopedia of the Chemical Elements, Clifford A. Hampel, ed., New York: Reinhold Book Corporation, 1968, pp. 822-830.

[24] R. Manivasagaperumal, S. Balamurugan, G. Thiyagarajan and J. Sekar, Effect of Zinc on Germination, Seedling Growth and Biochemical Content of Cluster Bean (Cyamopsis tetragonoloba (L.) Taub), Current Botany 2(5) (2011), 11-15.

[25] W. Maret and H. H. Sandstead, Zinc requirements and the risks and benefits of zinc supplementation, J. Trace Elem. Med. Biol. 20 (2006), 3-18. https://doi.org/10.1016/j.jtemb.2006.01.006

[26] NASA, Contributor Five Year Wikinson Microwave Anisotropy Probe (WMAP) observations: Data processing, Sky Maps and Basic Results (PDF), NASA, Retrieved March 6, 2008.

[27] S. P. Nations, P. J. Boyer, L. A. Love, M. F. Burritt, J. A. Butz, G. I. Wolfe, L. S. Hynan, J. Reisch and J. R. Trivedi, Denture cream: An unusual source of excess zinc, leading to hypocupremia and neurologic disease, Neurology 71(9) (2008), 639-643. https://doi.org/10.1212/01.wnl.0000312375.79881.94

[28] I. L. Nonnecke, Vegetable Production, Springer, 1989. 
[29] J. N. Pearson, Z. Rengel, C. F. Jenner and R. D. Graham, Manipulation of xylem transport affects $\mathrm{Zn}$ and $\mathrm{Mn}$ transport into developing wheat grains of cultured ears, Physiologia Plantarum 98 (1996), 229-234.

https://doi.org/10.1034/j.1399-3054.1996.980202.x

[30] A. S. Prasad, Zinc deficiency: its characterization and treatment, Met. Ions Biol. Syst. 41 (2004), 103-137.

[31] A. S. Prasad, F. W. Beck, S. M. Grabowski, J. Kaplan and R. H. Mathog, Zinc deficiency: changes in cytokine production and T-cell subpopulation in patients with head and neck cancer and in noncancer subjects, Proc. Assoc. Am. Physicians 109 (1997), 68-77.

[32] A. S. Prasad, Zinc: an overview, Nutrition 11 (1995), 93-99.

[33] A. Rashid, F. M. Chaudhry and M. Sharif, Micronutrient availability to cereals from calcareous soils, III. Zinc absorption by rice and it's inhibition by important ions of submerged soils, Plant and Soil 45 (1976), 613-623. https://doi.org/10.1007/BF00010583

[34] R. J. Richards, R. J. Applegate and A. I. M. Ritchie, The Rum Jungle Rehabilitation Project, in: Environmental Management in the Australian Minerals and Energy Industries: Principles and Practices, D. R. Mulligan, ed., pp. 530-553, University of New South Wales Press, Sydney, 1996.

[35] L. Rink, Zinc and the immune systems, Proc. Nutr. Soc. 59 (2000), 541-552. https://doi.org/10.1017/S0029665100000781

[36] H. H. Sandstead, Understanding zinc recent observations and interpretation, J. Lab. Clin. Med. 124 (1994), 322-327.

[37] K. Simmer and R. P. H. Thompson, Zinc in the fetus and newborn, Acta Padiatrica 74 (1985), 158-163. https://doi.org/10.1111/j.1651-2227.1985.tb10126.x

[38] N. W. Solomons, Mild human zinc deficiency produces an imbalance between cellmediated and humoral immunity, Nutr. Rev. 56 (1998), 27-28.

https://doi.org/10.1111/j.1753-4887.1998.tb01656.x

[39] J. Stary and J. O. Liljenzin, Critical evaluation of equilibrium constants involving acetylacetone and its metal chelates, Pure and Applied Chemistry 54(12) (1982), 25572592. https://doi.org/10.1351/pac198254122557

[40] G. D. Straganz, A. Glieder, L. Brecker, D. W. Ribbons and W. Steiner, Acetylacetonecleaving enzyme Dke1: a novel C-C-bond-cleaving enzyme from Acinetobacter johnsonii, Biochem. J. 369(3) (2003), 573-581. https://doi.org/10.1042/bj20021047

[41] Albert Stwerka, Zinc Guide to the Elements, Revised ed., Oxford University Press, 1998. 
[42] G. Thiyagarajan, R. Umadevi and K. Ramesh, Hydroponics, Science Tech Entrepreneur, Water Technology Centre, Tamil Nadu Agricultural University, Coimbatore, Tamil Nadu 641003, India, 2007.

[43] J. D. Wolt, Soil Solution Chemistry: Applications to Environmental Science, John Wiley and Sons, New York, 1994. 